Therapeutic implications of these results are controversial: Owen et al. (1969) showed that following experimental coronary artery occlusion the ischaemic area of myocardium depends on glycolysis for its energy metabolism. They point out that it might be important to provide adequate supplies of glucose for survival of the ischaemic area of muscle surrounding an infarct. Since heart muscle is insulin-sensitive and we have demonstrated suppression of insulin secretion in acute myocardial infarction, it seems logical to give insulin as well.

Oliver et al. (1968) and Kurien et al. (1969) showed a correlation between high levels of free fatty acids and the incidence of arrhythmias after myocardial infarction. If these are cause and effect, as seems likely from those authors' evidence, rather than two manifestations of the greater sympathetic activity in severe cases, then glucose and insulin would be useful in lowering free fatty acid levels.

A recent letter from Sodi-Pallares et al. (1969) pointed out that trials to test their regimen of potassium, glucose, and insulin in acute myocardial infarction have either not used the same route of administration or have not used anywhere near the same dosage of these substances which they advocate (M.R.C. Working Party, 1968 ; Pentecost et al., 1968). We have used large doses of insulin (200 units daily) and $50 \%$ glucose ( 1 litre daily) in the treatment of the "sick cell syndrome" of burned patients and of patients with chronic congestive cardiac failure (Hinton et al., in preparation). This measure has produced a rapid return of electrolyte biochemistry to normal. It is conceivable that such a mechanism might operate in a localized area of ischaemic myocardium and that the potassium, glucose, and insulin regimen of Sodi-Pallares et al. should be evaluated with an entirely different order of insulin and glucose dosage to that previously used in this country.

We thank Miss Ann Unitt and Mrs. Christine Haynes for technical help; Professor T. P. Whitehead and the department of biochemistry for measuring blood sugar levels; Dr. R. F. Fletcher for his encouragement and helpful criticism; Professor W. Melville Arnott for his support; and Dr. P. H. Davison, Professor John Bishop, and Dr. Gordon Cumming for allowing us to study patients under their care. We also thank the Medical Research Council for supporting one of us (S. P. A.) and financing purchase of equipment.

Requests for reprints should be sent to S. P. Allison, Department of Biochemistry, University of Bristol, Bristol.

\section{REFERENCES}

Allison, S. P., Hinton, Pamela, and Chamberlain, M. J. (1968). Lancet, 2, 1113. Allison, S. P., Prowse, K., and Chamberlain, M. J. (1967). Lancet, 1,

Allison, S. P., Tomlin, P. J., and Chamberlain, M. J. (1969). British Fournal of Anaesthesia, 41, 588 .

Coore, H. G., and Randle, P. J. (1964). Biochemical fournal, 93, 66. Dole, V. P., and Meinertz, H. (1960). Journal of Biological Chemistry, 235, 2595 .

Duncombe, W. G. (1963). Biochemical fournal, 88, 7.

Dykes, J. R. W., Saxton, C., and Taylor, S. H. (1969). British Medical fournal, 2, 490.

Ellenberg, M., Osserman, K. E., and Pollack, H. (1952). Diabetes, 1,

16. C. N., and Randle, P. J. (1963). Biochemical fournal, 88, 137.

Kosaka, K., et al. (1964). Endocrinology, 75, 9.

Kosaka, K., et al. (1964). Endocrinology, 75, 9.

Kurien, V. A., Yates, P. A., and Oliver, M. F. (1969).
Loubatieres, A., et al. (1965). Diabetologia, $1,13$.

Loubatierres, A., et al. (1965). Diabetologia, 1, 13.

Medical Research Council Working Party (1968). Lancet, 2,

Oliver, M. F., Kurien, V. A., and Greenwood, T. W. (1968). Lancet, 1, 710.

Owen, Patricia, Thomas, M., and Opie, L. (1969). Lancet, 1, 1187.

Pentecost, B. L., Mayne, N. M. C., and Lamb, P. (1968). Lancet, 1,

946. fournal of Clinical Investigation, 45, 228.

Randle, P. J., Garland, P. B., Hales, C. N., and Newsholme, E. A. (1963). Lancet, 1,785.

Ross, H., Johnston, I. D. A., Welborn, T. A., and Wright, A. D. (1966). Lancet, 2, 563.

Samols, E., and Marks, V. (1965). Lancet, 1, 462. Lancet, 1,1315 .
Lallares, D., de

Vallance-Owen, J., and Ashton, W. L. (1963). Lancet, 1, 1226.

Valori, C., Thomas, M., and Shillingford, J. P. (1967). Lancet, 1, 127.

\title{
Intraluminal Transport of Iron from Stomach to Small-intestinal Mucosa
}

\author{
A. JACOBS,* M.D., M.R.C.PATH.; P. M. MILES, $\dagger$ B.SC.
}

Summary : Inorganic iron rarely exceeds $10^{-4}$ molar $N$ concentration in the stomach after a meal. Natural sugars, ascorbic acid, citric acid, and amino-acids form iron complexes, and if they are present in the meal complexing occurs when the gastric contents are neutralized. In their absence an iron complex is formed with gastric mucopolysaccharide, which acts as a carrier, stable at neutral $p H$. Iron can be detached from this carrier at neutral $p H$ by some low molecular weight substances, of which citric acid, ascorbic acid, and cysteine are particularly effective at low concentrations. Under normal circumstances most of the iron released from food in the stomach becomes bound to the mucopolysaccharide carrier.

* Reader in Haematology.

+ Research Assistant.

Welsh National School of Medicine, Cardiff

\section{Introduction}

The existence of specific gastric factors which influence iron absorption has been postulated by several workers. Some have suggested that gastric juice contains a substance which potentiates inorganic iron absorption and that the level of absorption is regulated by variation in the amount secreted (Koepke and Stewart, 1964; Murray and Stein, 1968). Davis, Luke, and Deller (1966) measured gastric iron binding in vitro and found an iron-binding substance of high molecular weight in the gastric juice of healthy subjects, which they called "gastroferrin." Gastroferrin was absent or greatly reduced in amount in patients with idiopathic haemochromatosis and in irondeficiency anaemia (Luke, Davis, and Deller, 1967). They assumed that its normal action was to inhibit iron absorption.

Neither of these hypotheses has been supported by the observations of other investigators. Mignon et al. (1965) were 
unable to detect any stimulating effect of gastric juice from anaemic dogs on iron absorption. Neither did the administration of gastric juice from anaemic patients to normal persons together with a test dose of inorganic iron potentiate absorption (Jacobs, Rhodes, and Eakins, 1967). Recent measurements of iron-binding capacity of gastric juice in patients with haemochromatosis and iron-deficiency anaemia have shown no difference from the normal range, and there appears to be no relation between gastric iron-binding capacity and iron absorption in the same patient (Wynter and Williams, 1968 ; Jacobs and Miles, 1969a).

Most of the iron released from food by peptic digestion is in an ionizable form (Jacobs and Greenman, 1969). At the acid $p \mathrm{H}$ normally found in the stomach it exists as a chemically reactive solvated ferric ion of low molecular weight. When the gastric contents pass on into the upper jejunum, mixing with pancreatic and intestinal secretions results in a rise in $p H$ which approaches neutrality. Under these circumstances ionic iron either combines with other substances present with it in solution or undergoes polymerization and precipitation as ferric hydroxide (Jacobs and Miles, 1969b). Gastric juice normally contains a large amount of iron-binding mucopolysaccharide (Jacobs and Miles, 1969a), and under special circumstances other complexing agents may also be present which may form either soluble complexes, such as ferric ascorbate, or insoluble compounds, such as ferric phytate. Precipitated iron is clearly unavailable for absorption, and a complex soluble at neutral $\mathrm{pH}$ must be formed if iron is to be available to the mucosal cells. Low molecular weight complexes may be absorbed as such, but the complex formed with gastric mucopolysaccharide has a molecular weight above 200,000 and is unlikely to enter the epithelial cells in that form.

At present the relative importance of iron binding by gastric mucopolysaccharide and low molecular weight ligands is not known. This paper presents data on the physiological reactions of inorganic iron in the upper gastrointestinal tract. All iron determinations were carried out by the method of Young and Hicks (1965), and the resulting figures show the concentration of ionizable iron in the specimens. Iron-free glassware was used throughout the investigation. All physiological iron complexes are detected by this method with the exception of haem, which is not considered here.

\section{Concentration of Iron in Stomach}

Fully informed consent was obtained from all subjects undergoing intubation. In many of the cases where volunteers were members of the hospital staff a full discussion of the purpose of the investigation took place.

Samples of gastric juice were obtained from subjects with normal stomachs following an overnight fast. There were no signs of haemorrhage. The mean iron concentration of 31 resting samples was $14.45 \pm 1.25 \mu \mathrm{g} . / 100 \mathrm{ml}$, , and the mean concentration of 33 samples taken during the period of maximal secretion after an injection of synthetic pentapeptide (Pentavlon) was $13.48 \pm 0.69 \mu \mathrm{g} . / 100 \mathrm{ml}$.

The iron concentration in the stomach was measured in 18 subjects following a test meal consisting of shepherd's pie and peas taken together with $200 \mathrm{ml}$. of water. Two types of shepherd's pie were used with a different iron content. The basic ingredients of each meal before cooking were as follows :

Meal A.-Shepherd's pie: minced stewed steak 2 oz. (56 g.), potato $3 \mathrm{oz}$. ( $85 \mathrm{~g}$.), meat stock $2 \frac{1}{2} \mathrm{oz}$. $(71 \mathrm{ml}$.), and peas $2 \mathrm{oz}$. (56 g.). Iron content $3.45 \mathrm{mg}$.

Meal B.-Shepherd's pie: minced meat (raw) $3 \frac{1}{2}$ oz. (99 g.), potato $3 \mathrm{oz}$. ( $85 \mathrm{~g}$.) (cooked haemoglobin equivalent to $4.6 \mathrm{mg}$. $\mathrm{Fe}$ ), water $50 \mathrm{ml}$., and peas $2 \mathrm{oz}$. (56 g.). Iron content $8.05 \mathrm{mg}$.

In each case the total iron content of a duplicate meal was determined by a wet ashing technique. The subjects were fasted overnight and a gastric tube was passed through the nose in the morning. A resting specimen of juice was obtained and a $20-\mathrm{ml}$. sample was obtained at hourly intervals after the meal was eaten. These were centrifuged and filtered through Whatman No. 1 paper before iron determinations were carried out.

In normal subjects the mean $\mathrm{pH}$ of one-hour samples was $3 \cdot 1$, of two-hour samples $1 \cdot 9$, and of three-hour samples $1 \cdot 6$. The iron concentration rose in the first hour and in most cases had fallen again three hours after the meal (Table I). Meal B, with a higher iron content, gave rather higher concentrations even though initially most of the additional iron was probably in the form of haem compounds. Fig. 1 shows the variation in iron concentrations found in individuals given meal $B$. In three subjects with complete gastric atrophy the $\mathrm{pH}$ of aspirated samples varied from 6.1 to 7.9 and the iron concentrations were lower than normal.

TABLE I.-Concentration of Ionizable Iron in Stomach at Intervals After

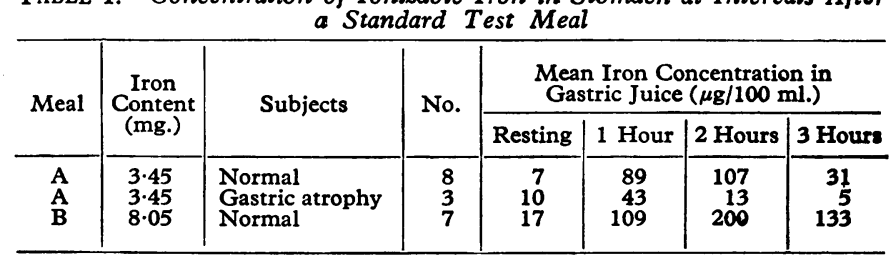

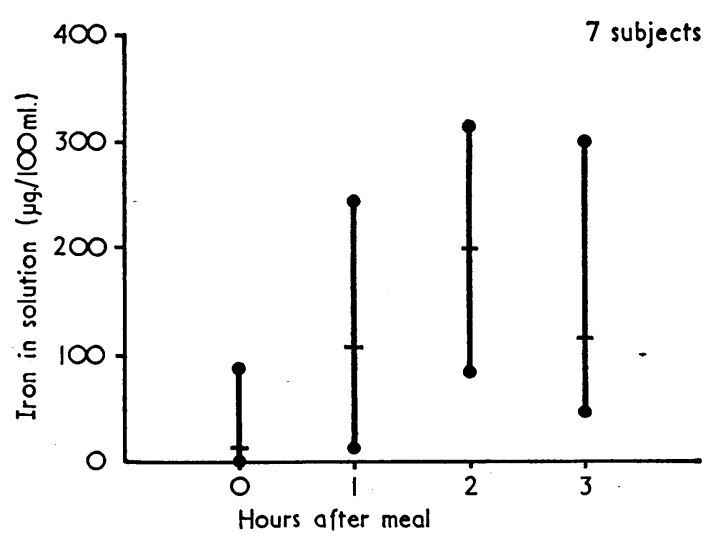

Fig. 1.-Gastric iron concentration after test meal B containing $8.05 \mathrm{mg}$. of iron. The mean and range of values are shown.

Under normal physiological circumstances the concentration of iron in the stomach is unlikely to exceed $10^{-4} \mathrm{M}(560 \mu \mathrm{g} . /$ $100 \mathrm{ml}$.) even after an iron-rich meal. This concentration of iron has been used to determine the binding capacity of various potential complexing agents which could be of importance in vivo.

\section{Iron Binding by Low Molecular Weight Components of Food}

Acid gastric juice will bind inorganic iron at a concentration of $10^{-4} \mathrm{M}$ when they are mixed together and then neutralized (Jacobs and Miles, 1969a, 1969b). This is due to the presence of mucopolysaccharide substances of high molecular weight. Many low molecular weight compounds appear in the gastrointestinal tract after a meal, and some of these have been examined for their iron-binding properties, including the common sugars and amino-acids together with citric acid and ascorbic acid. In all cases equal volumes of $10^{-4} \mathrm{M}$ ferric chloride solution in $0.15 \mathrm{M}$ barbitone-acetate buffer at $2 \mathrm{H} 2$ and solutions of the potential ligand were mixed. The concentration of ligand was $10^{-2} \mathrm{M}, 10^{-1} \mathrm{M}$, and $1 \mathrm{M}$ in three separate experiments giving a ligand/iron molar ratio from $100: 1$ to $10,000: 1$. The mixtures were neutralized by the slow addition of $12.5 \mathrm{M} \mathrm{NaOH}$ through a fine capillary tube 
while vigorous agitation was maintained with a Fison Whirlimixer. The solutions were then left to stand at $\mathrm{pH} 7$ for 18 hours, at the end of which time any precipitated iron was removed by centrifugation. The amount of iron bound is expressed as the amount remaining in solution at $\mathrm{pH} 7$, as a percentage of the amount in solution at $p H 2$ (Table II). TABLE II.-Percentage Iron Binding by Different Concentrations of
Ligands Added to $10^{-4} M$ Ferric Chloride at $\mathrm{pH} 2$ and Followed by Neutralization

\begin{tabular}{|c|c|c|c|c|c|c|}
\hline \multirow{2}{*}{\multicolumn{4}{|c|}{ Ligand }} & \multicolumn{3}{|c|}{ Concentration } \\
\hline & & & & $1 \mathrm{M}$ & $10^{-1} \mathrm{M}$ & $10^{-2} \mathrm{M}$ \\
\hline $\begin{array}{l}\text { Glucose } \\
\text { Fructose } \\
\text { Galactose } \\
\text { Maltose } \\
\text { Sucrose .. } \\
\text { Lactose .. }\end{array}$ & $\begin{array}{l}. \\
\ddot{ } \\
\ddot{.}\end{array}$ & $\begin{array}{l}\because \\
\because \\
\because \\
\end{array}$ & $\begin{array}{l}\ddot{ } \\
\ddot{0} \\
\ddot{0}\end{array}$ & $\begin{array}{l}90 \\
96 \\
93 \\
95 \\
74 .\end{array}$ & $\begin{array}{r}3 \\
73 \\
4 \\
3 \\
4 \\
3\end{array}$ & $\begin{array}{l}2 \\
2 \\
6 \\
0 \\
5 \\
0\end{array}$ \\
\hline $\begin{array}{l}\text { Leucine } \\
\text { Lysine .. } \\
\text { Arginine . } \\
\text { Threonine } \\
\text { Phenylalanine } \\
\text { Alanine .. } \\
\text { Tyrosine . } \\
\text { Valine .. } \\
\text { Serine . . } \\
\text { Glycine . } \\
\text { Isoleucine } \\
\text { Glutamic acid } \\
\text { Histidine } \\
\text { Tryptophan } \\
\text { Aspartic acid } \\
\text { Methionine } \\
\text { Cystine ... } \\
\text { Proline .. } \\
\text { Cysteine }\end{array}$ & 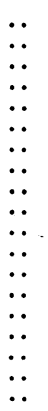 & $\begin{array}{l}\because \\
\because \\
\because \\
\because \\
\because \\
\because \\
\because \\
\because \\
\because \\
\because \\
\because\end{array}$ & $\begin{array}{l}\because \\
\because \\
\because \\
\because \\
\because \\
\because \\
\because \\
\because \\
\because \\
\therefore\end{array}$ & 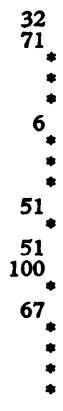 & $\begin{array}{r}3 \\
4 \\
2 \\
5 \\
3 \\
0 \\
3 \\
0 \\
64 \\
3 \\
2 \\
3 \\
0 \\
9 \\
40 \\
3 \\
5 \\
3 \\
100\end{array}$ & $\begin{array}{r}\mathbf{0} \\
2 \\
0 \\
0 \\
3 \\
0 \\
2 \\
0 \\
8 \\
3 \\
0 \\
0 \\
0 \\
7 \\
5 \\
0 \\
0 \\
0 \\
77\end{array}$ \\
\hline $\begin{array}{l}\text { Citric acid } \\
\text { Ascorbic acid } \\
\text { Sodium N.T.A. }\end{array}$ & $\because$ & $\because$ & $\ddot{0}$ & $\overline{-}$ & 三 & $\begin{array}{r}100 \\
98 \\
98\end{array}$ \\
\hline
\end{tabular}

* Ligand not completely soluble at this concentration.

Many of the substances tested were not soluble enough to produce a molar solution. All the sugars except lactose formed iron complexes at this concentration where the sugar/iron molar ratio was $10,000: 1$. Only fructose formed a complex at a lower concentration, but a fructose/iron ratio of $100: 1$ was not enough to ensure that iron was maintained in a complex form. At first sight these high sugar concentrations appear to be unphysiological, but sometimes this is not so. Coffee drinkers commonly add sucrose to their drink at $0 \cdot 2-0.3 \mathrm{M}$ concentration, and fruit juices may contain $0.3-0.4 \mathrm{M}$ fructose. The average daily sugar consumption per head in the United Kingdom is about $143 \mathrm{~g}$. and in the United States it is about 132 g. (International Sugar Council, 1967).

Among the substances tested only fructose, serine, aspartic acid, and cysteine show any effective iron binding at $10^{-1} \mathrm{M}$ concentration. Cysteine is a particularly strong binder and complexed most of the available iron at a $10^{-2} \mathrm{M}$ concentration. Ascorbic acid and citric acid bound most of the available iron at a $10^{-2} \mathrm{M}$ concentration.

\section{Gastric Iron Binding in vivo}

A few experiments were carried out in healthy control subjects to determine whether the iron released from food by peptic digestion is normally bound by gastric mucopolysaccharide in a non-dialysable form or whether sufficient low molecular weight components of food are normally present to form dialysable complexes of small molecular size. Dialysis was carried out against $0.15 \mathrm{M}$ barbitone-acetate (Michaelis) buffer with Visking tubing grade $18 \mathrm{DC}$.

In three subjects the standard meal $B$ was eaten after an overnight fast, and $200 \mathrm{ml}$. of water was drunk during the meal. Gastric samples were collected through an indwelling tube at hourly intervals. All three results showed the same pattern (Fig. 2). In this case the gastric $\mathrm{pH}$ remained within the range 1.2-1.6 throughout the test period, and the concentration of ionizable iron rose in the first hour and fell again in the third hour. When the specimens were dialysed against buffer at gastric $\mathrm{pH}$ almost all the iron was removed. Aliquots of the samples were neutralized and allowed to stand overnight before centrifugation to remove any precipitated iron. When the iron estimations were repeated before and after dialysis most of the iron was found to be in a non-dialysable form. Under the conditions in which this meal was given the liberated iron was in the form of a low molecular weight complex at acid $p H$, but after neutralization binding to gastric mucopolysaccharide occurred with the formation of a high molecular weight complex.

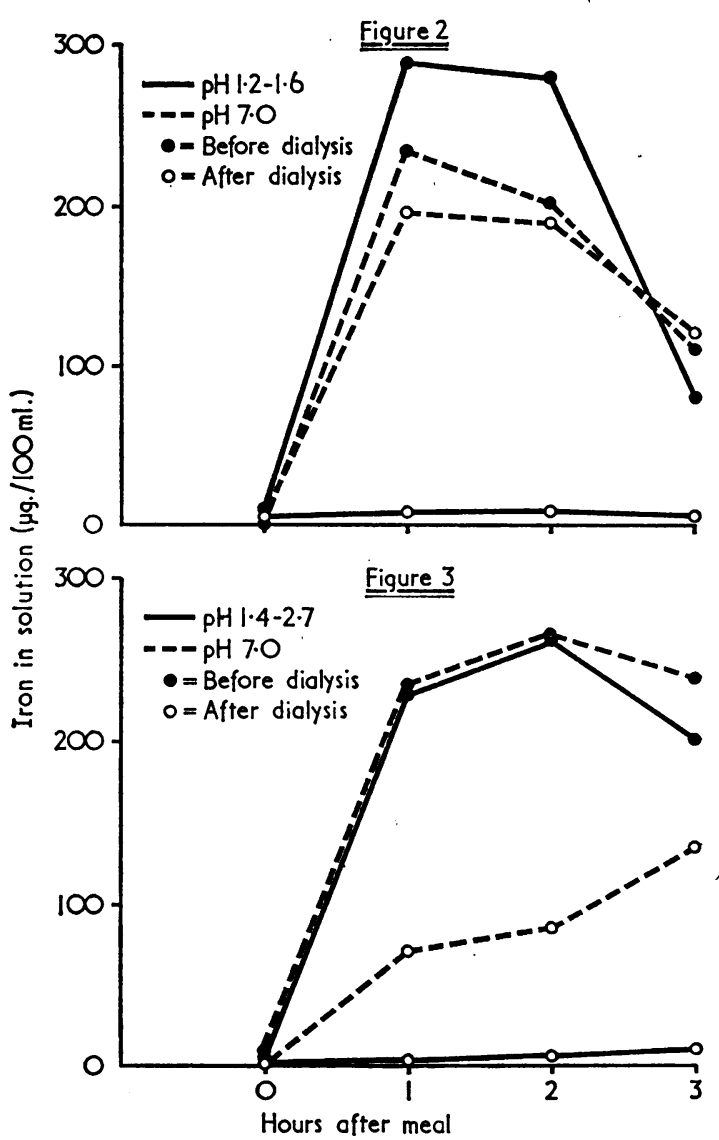

FIG. 2.-Gastric iron concentration after test meal B showing the amount of iron before and after dialysis at acid Fig. 3.- Gastric iron concentration after test meal $B$ given together with $200 \mathrm{ml}$. of orange juice. The results are shown as in Fig. 2.

Three further subjects were given the same meal, and on this occasion $200 \mathrm{ml}$. of Heinz orange juice was taken together with the food. The concentrations of iron appearing in the acid aspirates after the meal (Fig. 3) were similar to those found previously and the iron was completely dialysable. In neutralized aliquots of the gastric samples most of the iron remained dialysable in the one-hour and two-hour specimens, and only in the three-hour specimens did non-dialysable iron constitute the major component. Heinz orange juice contains $4 \times 10^{-3} \mathrm{M}$ ascorbic acid, $6 \times 10^{-2} \mathrm{M}$ citric acid, $7 \times 10^{-2} \mathrm{M}$ sucrose, $2.3 \times 10^{-1} \mathrm{M}$ fructose, and $2.3 \times 10^{-1} \mathrm{M}$ glucose (Heinz, personal communication). These substances appear to have maintained the iron released from food in a dialysable form even after neutralization of the gastric contents. These low molecular weight ligands have already been shown to have iron-binding properties, and if they are present in a high enough concentration they can compete with gastric mucopolysaccharide for ionizable iron in the stomach. Under normal circumstances, when fruit juice is not taken with a meal, ionizable iron will combine with gastric mucopolysaccharide when the gastric contents are neutralized and will appear in the jejunal 
lumen as a large molecular complex, which is unlikely to be absorbed in that form.

\section{Reaction of Iron-mucopolysaccharide Complex and Iron-binding Substances}

In the absence of binding agents such as ascorbic acid and fructose in the stomach formation of an iron-mucopolysaccharide complex results in iron appearing in the jejunum in a soluble large molecular form. Unless specific receptor sites for iron are present on the intestinal cells, where the metal can be detached from this complex and absorbed, then an alternative method of release must be available. Such receptor sites are unlikely to exist, and we have investigated the possibility that low molecular weight ligands formed by food digestion in the small intestine can detach iron from its carrier mucopolysaccharide to produce small absorbable complexes. Many of the amino-acids and monosaccharides already studied are released at this level following the action of pancreatic and intestinal enzymes, and these have been re-examined in this context.

An iron-mucopolysaccharide complex was formed by mixing ferric chloride solution and filtered gastric juice at $\mathrm{pH} 2$ followed by neutralization. The concentration of iron in the resulting solution was $10^{-4} \mathrm{M}$, entirely in a non-dialysable form. Aliquots of this solution were mixed with equal volumes of neutral solutions containing the substances listed in Table II at concentrations from $1 \mathrm{M}$ to $10^{-4} \mathrm{M}$. The mixtures were incubated for one hour at $37^{\circ} \mathrm{C}$. and then transferred to bags of Visking tubing for dialysis against $0.15 \mathrm{M}$ barbitone-acetate buffer at $\mathrm{pH} 7$. Iron removed from the mucopolysaccharide and forming a low molecular weight complex passes out of the dialysis bag during this process, and hence iron concentration in the bag falls. Most of the compounds in Table II produced no change of iron concentration in the dialysis bag. Many of the compounds forming iron complexes were unable to detach iron from the mucopolysaccharide. The strongest iron binders, cysteine, citric acid, and ascorbic acid, were all able to remove iron from the mucopolysaccharide complex, the two last compounds even having some effect when their concentration was no greater than that of the iron (Table III). Two non-physiological iron-binding substances, sodium nitrilotriacetate (sodium N.T.A.) and edetic acid were also tested and both these effectively removed iron from the mucopolysaccharide complex.

TABLE III.-Percentage Iron Removed from Iron-mucopolysaccharide Complex After One Hour's Incubation with Different Concentrations of Ligands

\begin{tabular}{|c|c|c|c|c|c|}
\hline \multirow{2}{*}{ Ligand } & & \multicolumn{4}{|c|}{ Concentration } \\
\hline & & $10^{-1} \mathrm{M}$ & $10^{-2} \mathrm{M}$ & $10^{-3} \mathrm{M}$ & $10^{-4} \mathrm{M}$ \\
\hline $\begin{array}{ll}\text { Cysteine } & \ldots \\
\text { Citric acid } & \ldots \\
\text { Ascorbic acid } \\
\text { Sodium N.T.A. } \\
\text { Edetic acid }\end{array}$ & $\begin{array}{l}\because \\
\because \\
\ddot{y}\end{array}$ & $\begin{array}{l}96 \\
\text { 二 }\end{array}$ & $\begin{array}{l}92 \\
87 \\
92 \\
97 \\
97\end{array}$ & $\begin{array}{r}0 \\
60 \\
48 \\
87 \\
74\end{array}$ & $\begin{array}{r}0 \\
13 \\
15 \\
43 \\
16\end{array}$ \\
\hline
\end{tabular}

\section{Conclusions}

Under physiological circumstances the gastric concentration of ionizable iron is not high. The mean concentration of iron in resting gastric juice in this study was $14.45 \mu \mathrm{g} . / 100 \mathrm{ml}$., the highest value being $30 \mu \mathrm{g} . / 100 \mathrm{ml}$. Murray and Stein
(1968) found values as high as $320 \mu \mathrm{g} / 100 \mathrm{ml}$. , but some of their subjects were suffering from haemochromatosis. The high levels recorded by Kimura and Yamana (1967) were not found in this study, nor did we find lower levels in iron-deficient subjects than in normal controls (unpublished data). Few normal meals contain more than about $8 \mathrm{mg}$. of iron, and $20-40 \%$ of this would be expected to be released in ionizable form as a result of peptic digestion (Jacobs and Greenman, 1969). The concentration of iron found in the stomach after meals in this study was of the order expected, allowing for the rate of gastric secretion, release of iron, and gastric emptying. It rarely exceeded $10^{-4} \mathrm{M}$.

Hence the iron released from food in the stomach probably binds to gastric mucopolysaccharide on neutralization unless an alternative ligand is present. Gastric juice thus provides a carrier of high molecular weight which can prevent the precipitation of iron in the small intestine. Competing ligands can appear at three sites in the gastrointestinal tract. If they are present in the diet they may form soluble complexes as the gastric contents are neutralized. This was found in the present study when orange juice was taken. If they are released in the intestinal lumen in sufficient quantities they may be able to remove iron from its carrier, but only a few of the substances tested here were effective in this respect. Monosaccharides and amino-acids are also formed as a result of digestion occurring at the brush border of intestinal cells, and there may be a high local concentration of these substances between the microvilli where conditions for complex formation may be more satisfactory than in the lumen.

The method by which iron passes from its mucopolysaccharide carrier into the gut cells is not entirely clear. The present work shows that it can be detached by small molecules, and there are many untested dipeptides and polypeptides which could function in this way. An alternative possibility is that the degradation of the carrier itself results in the appearance of low molecular weight iron-binding fractions that are available to the intestinal epithelium. Further elucidation of the intraluminal reactions of inorganic iron is necessary for a full understanding of its mucosal uptake and intracellular transport.

We are particularly grateful to the subjects who took part in these tests and to the members of the dietetics department who helped with the preparation of the meals.

This work was supported by a grant from the Endowment Fund of the United Cardiff Hospitals.

\section{REFERENCES}

Davis, P. S., Luke, C. G., and Deller, D. J. (1966). Lancet, 2, 1431. International Sugar Council (1967). Sugar Year Book, 1966. London, International Sugar Council.

Jacobs, A., and Greenman, D. A. (1969). British Medical fournal, 1, 673.

Jacobs, A., and Miles, P. M. (1969a). Clinica Chimica Acta, 24, 87 Jacobs, A., and Miles, P. M. (1969b). Gut, 10, 226.

Jacobs, A., Rhodes, J., and Eakins, J. D. (1967). Scandinavian fournal of Haematology, 4, 105.

Kimura, I., and Yamana, M. (1967). Acta Medicinae Okayama, 21, 177.

Koepke; J. A., and Stewart, W. B. (1964). Proceedings of the Society for Experimental Biology and Medicine, 115, 927.

Luke, C. G., Davis, P. S., and Deller, D. J. (1967). Lancet, 1, 926.

Mignon, M., et al. (1965). Surgical Forum, 16, 319.

Murray, M. J., and Stein, N. (1968). Lancet, 1, 614

Wynter, C. V. A., and Williams, R. (1968). Lancet, 2, 534.

Young, D. S., and Hicks, J. M. (1965). Fournal of Clinical Pathology, 